\title{
Pendidikan Kesehatan tentang Kebutuhan Gizi Remaja di Pondok Pesantren Al Kinanah Kota Jambi
}

\author{
Dini Junita ${ }^{1}$, Djayusmantoko \\ 1,2 Program Studi Ilmu Gizi, STIKes Baiturrahim Jambi \\ Email:dinijunita.dj.dj@gmail.com
}

Submitted : 24/03/2021

Accepted: 21/06/2021

Published: 28/06/2021

\begin{abstract}
Education on balanced nutrition is still unknown among the wider community, especially teenagers, therefore it is necessary to convey messages of balanced nutrition. The partner chosen in this outreach activity is the Al Kinanah Islamic Boarding School in Jambi City. Al Kinanah Islamic boarding school is one of the Islamic boarding schools in Jambi City. Islamic boarding schools are educational facilities that not only provide religious education, but also general education and independence for students. Students who live in Islamic boarding schools are accustomed to not using communication tools such as cell phones and television like teenagers in general, so that more information is received from the teachers. Efforts to increase knowledge about balanced nutrition in teenagers require a strategic approach to be achieved effectively and efficiently so that it can be applied. One method that can be used is poster and leaflet media. Based on the results obtained from this activity, it is known that the knowledge of the students regarding the guidelines for balanced nutrition is still low. Even though there is an increase, in general the knowledge of students only gets quite good (average score of 65.33). For this reason, it is necessary to carry out health education, especially nutrition in a sustainable manner, if possible it is included in the Islamic boarding school education curriculum. As well as providing health facilities that can be a medium for health information for students through posters or extracurricular organizations at Islamic boarding schools.
\end{abstract}

Keywords: balance nutrition, education, islamic boarding, teenager

\begin{abstract}
Abstrak
Pendidikan tentang gizi seimbang masih belum dikenal di kalangan masyarakat luas khususnya remaja maka dari itu perlu adanya penyampaian pesan-pesan gizi seimbang. Mitra yang dipilih dalam kegiatan penyuluhan ini adalah Pondok Pesantren Al Kinanah Kota Jambi. Pondok Pesantren Al Kinanah merupakan salah satu pondok pesantren yang berada di wilayah Kota Jambi. Pondok pesantren merupakan sarana pendidikan yang tidak hanya memberikan pendidikan agama, namun juga pendidikan umum dan kemandirian bagi santri. Santri yang tinggal di Pondok pesantren terbiasa untuk tidak menggunakan alat komunikasi seperti telepon genggam serta televisi seperti remaja pada umumnya, sehingga informasi yang diterima lebih banyak berasal dari para pengajar. Upaya untuk meningkatkan pengetahuan tentang gizi seimbang pada remaja memerlukan cara pendekatan yang strategis agar tercapai secara efektif dan efisien sehingga dapat diaplikasikan. Salah satu metode yang dapat digunakan adalah media poster dan leaflet. Berdasarkan hasil yang diperoleh dari kegiatan ini diketahui pengetahuan santri mengenai pedoman gizi seimbang masih rendah. Meskipun terdapat peningkatan namun secara umum pengetahuan santriwati hanya mendapat cukup baik (skor rata-rata 65,33), untuk itu perlu dilakukan pendidikan kesehatan khususnya gizi secara berkelanjutan, jika mungkin dimasukkan ke dalam kurikulum pendidikan pondok pesantren. Serta penyediaan sarana kesehatan yang dapat menjadi media informasi kesehatan bagi santriwati melalui poster ataupun organisasi ekstrakurikuler di Pondok Pesantren.
\end{abstract}

Kata Kunci : gizi remaja, gizi seimbang, pendidikan gizi, pesantren, remaja putri 


\section{PENDAHULUAN}

Masa remaja merupakan suatu masa transisi dari masa kanak-kanak ke masa dewasa dengan batasan usia 10-18 tahun, di mana secara fisik akan mengalami perubahan yang spesifik secara psikologik akan mencari identitas diri (Ningsih, 2018). Remaja dikategorikan rentan terhadap masalah gizi sehingga berisiko terhadap kesehatan. Pada usia remaja percepatan pertumbuhan dan perkembangan tubuh memerlukan energi lebih banyak selain itu, pada remaja terjadi perubahan gaya hidup dan kebiasaan yang suka mencoba-coba makanan sehingga asupan energi dan zat gizi lainnya (Marmi, 2013).

Permasalahan gizi banyak dijumpai pada usia remaja, diantaranya gizi lebih, obesitas, gizi kurang, anemia, pola makan yang salah dan sebagainya. Untuk mencegah timbulnya masalah gizi tersebut, perlu disosialisasikan pedoman gizi seimbang yang bisa dijadikan sebagai pedoman makan, beraktivitas fisik, hidup bersih dan mempertahankan berat badan normal. Pedoman gizi seimbang adalah konsumsi makan sehari-hari harus mengandung zat gizi dalam jenis dan jumlah (porsi) yang sesuai dengan kebutuhan setiap orang atau kelompok umur. Konsumsi makanan harus memperhatikan prinsip 4 piar yaitu keanekaragam pangan, perilaku hidup bersih, aktivitas fisik dan mempertahankan berat badan normal (Bina Gizi dan Kia. Kemenkes RI, 2014).

Masalah gizi yang timbul pada usia remaja dipicu oleh beberapa faktor seperti kebiasaan makan yang buruk, pemahaman gizi yang salah, kesukaan yang berlebihan terhadap satu jenis makanan, promosi yang berlebihan tentang produk makanan dimedia masa dan maraknya produk impor makanan. Pengetahuan pangan dan gizi juga merupakan salah satu faktor yang mempengaruhi status gizi sehingga diperlukan pendidikan gizi secara formal maupun non formal (Sulistyoningsih, 2012).

Kegiatan ini akan memberikan pendidikan gizi berupa pendidikan kesehatan mengenai kebutuhan gizi seimbang pada remaja. Pendidikan tentang gizi seimbang masih belum dikenal di kalangan masyarakat luas khususnya remaja maka dari itu perlu adanya penyampaian pesan-pesan gizi seimbang. Mitra yang dipilih dalam kegiatan penyuluhan ini adalah Pondok Pesantren Al Kinanah Kota Jambi. Pondok Pesantren Al Kinanah merupakan salah satu pondok pesantren yang berada di wilayah Kota Jambi. Pondok pesantren merupakan sarana pendidikan yang tidak hanya memberikan pendidikan agama, namun juga pendidikan umum dan kemandirian bagi santri. Santri yang tinggal di Pondok pesantren terbiasa untuk tidak menggunakan alat komunikasi seperti telepon genggam serta televisi seperti remaja pada umumnya, sehingga informasi yang diterima lebih banyak berasal dari para pengajar. Upaya untuk meningkatkan pengetahuan tentang gizi seimbang pada remaja memerlukan cara pendekatan yang strategis agar tercapai secara efektif dan efisien sehingga dapat diaplikasikan. Salah satu metode yang dapat digunakan adalah media poster dan leaflet. Berdasarkan uraian di atas maka penulis tertarik untuk melakukan pendidikan kesehatan mengenai pengetahuan kebutuhan gizi seimbang pada remaja di Pondok Pesantren Al Kinanah Kota Jambi.

\section{TARGET DAN LUARAN}

Berdasarkan permasalahan yang ada, tim pelaksana pengabdian masyarakat memberikan solusi berupa kegiatan pendidikan kesehatan tentang gizi seimbang bagi remaja. Kegiatan ini dilakukan dengan pendekatan langsung ke pihak Pondok pesantren dan santri menggunakan media yang diizinkan bagi santri berupa poster dan leaflet. Sehingga diharapkan dapat memberikan pengetahuan di bidang gizi 
dan kesehatan. Kegiatan penyuluhan ini memiliki target khusus yaitu :

1. Adanya santriwati Pondok Pesantren Al Kinanah Kota Jambi total 30 orang

2. Sasaran memiliki pengetahuan baik tentang kebutuhan gizi seimbang pada remaja. Indikator pengetahuan baik yaitu $\geq 80 \%$ sasaran dapat menjawab dengan benar pertanyaan pada lembar post-test.

Sedangkan luaran dari kegiatan ini selain peninggkatan pengetahuan berupa media poster, leaflet, artikel ilmiah.

\section{METODE PELAKSANAAN}

Kegiatan ini telah dilaksanakan pada bulan Februari 2020 berlokasi di Pondok Pesantren Al Kinanah Kota Jambi. Tahapan pelaksanaan kegiatan penyuluhan ini adalah sebagai berikut :

\section{Kegiatan Awal}
a. Menyusun proposal kegiatan pengabdian masyarakat
b. Mengurus perizinan ke pengurus Pondok Pesantren Al Kinanah
c. Mendesain poster dan leaflet gizi seimbang.

d. Menyiapkan materi persentasi gizi seimbang untuk disampaikan kepada sasaran.

e. Menyiapkan lembar pre-test dan post test tentang pengetahuan terkait gizi seimbang.

f. Menyiapkan souvenir yang akan dibagikan kepada santri-santri yang telah mengikuti kegiatan penyuluhan.

\section{Pelaksanaan Kegiatan}

a. Perkenalan antara tim penyuluhan kepada santriwati.

b. Penjelasan kegiatan yang akan dilakukan dalam melibatkan sasaran.

c. Memberikan lembar pre-test.

d. Melaksanakan penyampaian materi gizi seimbang pada remaja melalui poster dan leaflet.

e. Memberikan lembar post test.

f. Memberikan souvenir untuk santrisantri.

g. Penutupan.

\section{Monitoring dan Evaluasi}

Monitoring dan evaluasi (Monev) dilakukan dengan teknik wawancara dan observasi langsung kepada sasaran. Cakupan Monev dalam kegiatan ini meliputi aspek, yaitu sebagai berikut

\section{a. Monev Perencanaan}

Pada aspek ini tim akan mengevaluasi kondisi mitra, tujuan program, permasalahan dan pemecahan masalah, isi materi dan praktik kegiatan, media/alat yang digunakan, sasaran dalam kegiatan penyuluhan, waktu pelaksanaan evaluasi (berapa lama, dan kapan evaluasi dilakukan), sarana dan prasarana, dan dana yang digunakan.

\section{b. Monev Pelaksanaan Kegiatan}

Indikator keberhasilan pada aspek ini adalah :

1) Sebanyak 90-100\% sasaran menghadiri setiap pertemuan pada kegiatan penyuluhan.

2) Kemampuan tim menyampaikan materi dan praktik kepada sasaran.

3) Refleksi dan umpan balik dan peserta kegiatan.

\section{HASIL DAN PEMBAHASAN}

Pondok pesantren Al Kinanah Kota Jambi memiliki jumlah santriwati di Pesantren sebanyak 200 orang. Pesantren Al Kinanah terletak di Jl. Sumber Rejo Lingkar Barat RT.28 Kel. Mayang Mangurai Kec. Alam Barajo Kota Jambi. Pondok pesantren Al Kinanah diresmikan pada tanggal 11 Mei 2018 dengan luas areal dua hektar.

Sasaran dalam kegiatan penyuluhan ini adalah sebagian santriwati Pondok Pesantren Al Kinanah Kota Jambi sebanyak 30 orang. Pada pelaksanaannya semua santriwati menghadiri kegiatan sampai selesai sehingga capaian sasaran dalam kegiatan penyuluhan ini $100 \%$. Kegiatan ini didampingi oleh ustadzah yang mengajar di Pondok Pesantren Al Kinanah sehingga diharapkan ustadzah tersebut dapat mentransformasikan ilmu yang 
disampaikan serta memotivasi santriwati untuk menerapkan gizi seimbang.

Sebelum dilakukan kegiatan tim anggota memperkenalkan diri dan menjelaskan sedikit tujuan dari kegiatan penyuluhan ini kemudian peserta diberikan soal pre-test untuk mengukur pengetahuan awal sebelum diberikan penyuluhan. Pemberi materi disampaikan oleh semua anggota tim penyuluhan secara bergantian. Setelah dilakukan penyuluhan, sasaran diberikan soal post-test untuk mengukur pengetahuan sasaran setelah diberikan penyuluhan. Selain itu, pada pelaksanaan tim penyuluhan juga menunjukkan contoh makanan gizi seimbang seperti makanan sumber karbohidrat, protein, lemak, vitamin, serat dan mineral menggunakan food model yang sudah terdapat ukuran berat masing-masing makanan tersebut sehingga diharapkan dapat meningkatkan pengetahuan santriwati.

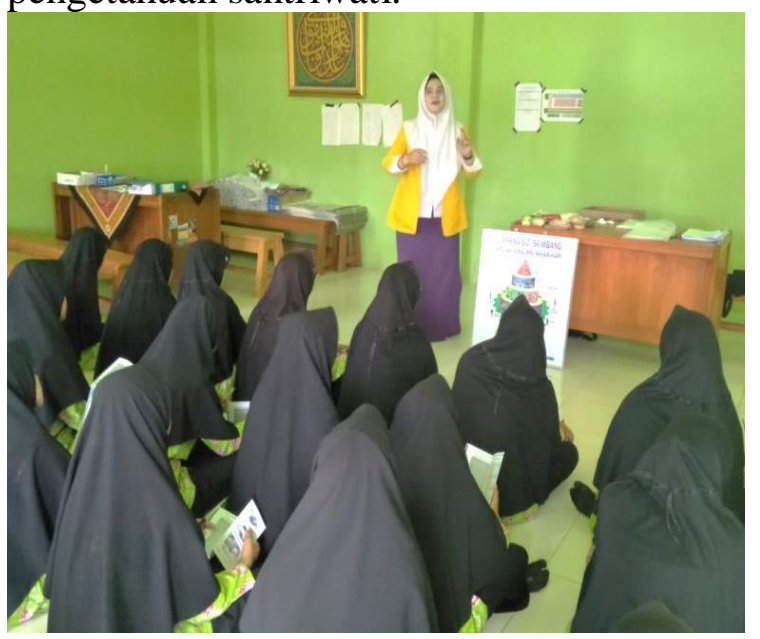

Gambar 1. Pemberian Materi Gizi Seimbang

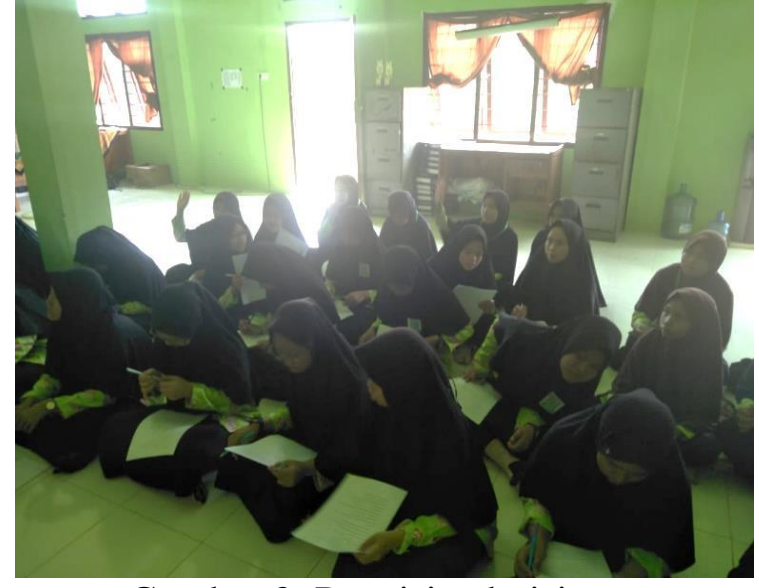

Gambar 2. Pengisian kuisioner

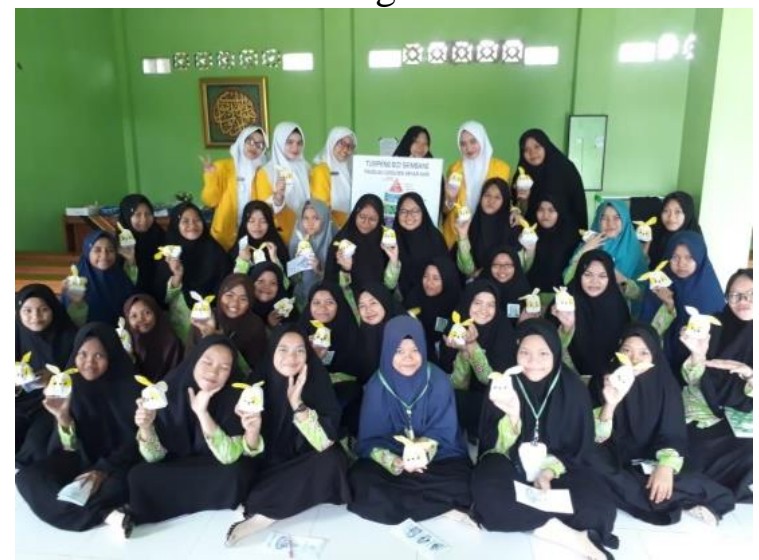

Gambar 3. Foto Bersama

Pada kegiatan pengabdian masyarakat pada santriwati di Pondok Pesantren Alkinanah, tim pengabdian juga melakukan pre-post test untuk melihat peningkatan pengetahuan sebelum dan setelah pemberian materi. Berdasarkan hasil rekap nilai yang diperoleh dapat dilihat pada tabel 1.

Tabel 1 Hasil nilai pre-post dan post-test

\begin{tabular}{cccc}
\hline \multirow{2}{*}{ Responden } & \multicolumn{2}{c}{ NILAI } & \multirow{2}{*}{ Peningkatan } \\
\cline { 2 - 3 } & Pre-test & Pos-test & \\
\hline 1. & 45 & 75 & 30 \\
2. & 50 & 70 & 20 \\
3. & 20 & 65 & 45 \\
4. & 55 & 70 & 15 \\
5. & 40 & 70 & 30 \\
6. & 45 & 70 & 25 \\
7. & 55 & 75 & 20 \\
8. & 40 & 65 & 25 \\
9. & 40 & 60 & 20 \\
10. & 50 & 80 & 30 \\
11. & 40 & 65 & 25 \\
12. & 55 & 85 & 30 \\
13. & 35 & 55 & 20 \\
\hline
\end{tabular}




\begin{tabular}{cccc}
\hline 14. & 35 & 55 & 20 \\
15. & 35 & 50 & 20 \\
16. & 35 & 60 & 25 \\
17. & 35 & 60 & 25 \\
18. & 35 & 60 & 25 \\
19. & 45 & 60 & 15 \\
20. & 50 & 65 & 14 \\
21. & 35 & 65 & 30 \\
22. & 30 & 75 & 45 \\
23. & 50 & 60 & 10 \\
24. & 35 & 55 & 20 \\
25 & 15 & 65 & 50 \\
26. & 25 & 55 & 30 \\
27. & 30 & 65 & 35 \\
28. & 35 & 65 & 30 \\
29. & 50 & 65 & 15 \\
30. & 50 & 75 & 25 \\
\hline Rata-rata & 39,83 & 65,33 & 25,63 \\
\hline
\end{tabular}

Berdasarkan hasil pre post test diketahui bahwa pengetahuan santriwati mengenai gizi seimbang diawal kegiatan sangat kurang dengan niali rata-rata 39.83. Setelah dilakukan penyuluhan berupa edukasi tentang gizi seimbang rata-rata nilai meningkat kurang lebih 25.63 poin sehingga nilai rata-rata nilai menjadi 65.33 dengan kriteria cukup baik. Berdasarkan reakpitulasi data dari 20 soal pre-test, salah satu pertanyaan yang paling banyak jawaban yang salah, dijawab oleh santriwati yaitu pada soal nomor 8 yaitu pertanyaan mengenai dampak dari kurangnya asupan serat. Pertanyaan ini hanya dijawab dengan benar oleh 2 orang santri. Ketika ditanyakan kembali santri mengatakana bahwa istilah itu tidak pernah di dengar oleh santriwati dalam kehidupan sehari, padahal istilah kesehatan yang digunakan sangatlah umum. Sedangkan pada saat postest pertanyaan yang paling banyak salah dijawab yaitu pada soal nomor 20, mengenai anjuran pemantauan berat badan hanya 3 orang yang menjawab dengan benar.

Perubahan dan peningkatan nilai pengetahuan pada responden dimungkinkan karena berbagai hal yang berkaitan dengan proses penyuluhan diantaranya adalah materi yang terdapat dalam media yang menarik minat responden dan metode pendidikan yang menarik berupa permainan, sehingga responden mudah untuk memahami isi materi pendidikan kesehatan yang disampaikan. Kondisi tersebut sesuai dengan pernyataan yang disampaikan oleh WHO dalam Mubarak (2007) bahwa pengunaan metode/media pendidikan sangat menentukan keberhasilan penyampaian pendidikan kesehatan. Hal ini juga didukung dengan penelitian Wawan (2010), mengemukakan bahwa penyuluhan dengan media mampu meningkatkan pengetahuan dan sikap antara lain penyuluhan kepada remaja terhadap pentingnya sarapan dengan menggunakan media booklet.

Santriwati yang menjadi sasaran saat penyuluhan mengakui bahwa mereka sangat jarang mengkonsumsi makanan yang beraneka ragam. Mereka jarang mengkonsumsi sayur dan rata-rata tidak suka dengan sayur yang disajikan oleh pondok pesantren tersebut. Sehingga pemateri menjelaskan pentingnya mengkonsumsi makanan beraneka ragam serta pentingnya menerapkan pedoman gizi seimbang. Setelah diberikan penjelasan, sasaran langsung memberikan pertanyaan kepada pemateri apa dampak jika tidak mengkonsumsi makanan yang beragam. Kemudian pemateri memberikan jawaban dan solusi bagaimana mengatur pola makan yang seimbang atau beragam serta menjelaskan apa saja dampak yang didapatkan apabila tidak menerapkan pedoman gizi seimbang. Penyuluhan dibutuhkan bagi peserta, kebanyakan peserta mengeluhkan kurangnya pengetahuan tentang gizi seimbang pada remaja putri, sehingga mereka mengkonsumsi makanan semau dan sesuka mereka saja. Untuk itu diperlukan sosialisasi lebih intensif mengenai gizi seimbang pada remaja putri sehingga dapat meningkatkan pengetahuan remaja putri tentang pentingnya menerapkan gizi seimbang dalam pola kehidupannya seharihari. 
Meskipun terdapat peningkatan pengetahuan namun secara umum pengetahuan santriwati masih belum dikategorikan baik, untuk itu perlu dilakukan pendidikan kesehatan khususnya gizi secara berkelanjutan, jika mungkin dimasukkan ke dalam kurikulum pendidikan pondok pesantren. Hal ini sesuai dengan teori bahwa keberhasilan proses pendidikan dipengaruhi oleh beberapa faktor, antara lain ; penyelenggara pendidikan, sarana dan fasilitas, kurikulum, peserta didik, dosen/instruktur, metode dan media pembelajaran (Depkes, 2005). Selain itu salah satu faktor yang mempengaruhi dari keberhasilan proses pendidikan adalah media pembelajaran. Penggunaan media poster akan sangat baik jika diterapkan di Pondok pesantren, sebab mudah terlihat dan dapat menjadi kebiasaan yang diterapkan dalam kehidupan sehari-hari.

\section{KESIMPULAN DAN SARAN}

\section{Kesimpulan}

Berdasarkan kegiatan penyuluhan yang telah dilaksanakan di Pondok Pesantren Al Kinanah Kota Jambi, maka dapat disimpulkan pendidikan kesehatan yang diberikan dapat meningkatkan pengetahuan pada sasaran dari kurang menjadi cukup baik dengan skor ratarata 39,8 menjadi skor rata-rata 65,3 .

\section{Saran}

Berdasarkan hasil kegiatan dan pengamatan di Pondok Pesantren AL Kinanah diperlukan pemantauan asupan gizi santriwati yang melibatkan ustadzah dan keluarga. Serta perlunya penyediaan sarana kesehatan yang dapat menjadi media informasi kesehatan bagi santriwati melalui poster ataupun organisasi ekstrakurikuler di Pondok Pesantren.

\section{UCAPAN TERIMAKASIH}

Tim pengabdian mengucapkan terimakasih kepada STIKes Baiturrahim Jambi atas dukungan moril serta materi yang bersumber dari dana pengabdian internal STIKBA sehingga kegiatan ini dapat terlaksana dengan baik. Serta terimakasih untuk semua Ustadzah dan pimpinan Pondok Pesantren Al Kinanah atas izin melakukan kegiatan ini.

\section{DAFTAR PUSTAKA}

Atmarita \& Fallah, S.T. 2004. Analisis Situasi Gizi dan Kesehatan Masyarakat.

DEPKES RI, Pedoman Pengembangan Metodologi Pembelajaran Pendidikan Tenaga Kesehatan. Pusat Pendidikan Tenaga Kesehatan Badan Pengembangan dan Pemberdayaan SDM Kesehatan Departemen Kesehatan, Jakarta, 2005.

Kementerian Kesehatan RI. (2014). Pedoman Gizi Seimbang. Jakarta. (htto://gizi.depkes.go.id/doenloead/Pe doman\%20Gizi/PGS\%200k:pdf, diakses 27 mei 2019, Pukul 20:30 wib)

Kusuma N.I. 2014. Pengaruh Pendidikan Kesehatan Anemia Pada Remaja Putri Terhadap Tingkat Pengetahuan dan Sikap Dalam Mencegah Anemia Pada Siswi Kelas X SMA Muhamadiyah 5 Yogyakarta Tahun 2014. Naskah Publikasi.

Marmi. 2013. Gizi Dalam Kesehatan Reproduksi. Yogyakarta : Pustaka Pelajar.

Ningsih, S, H. (2018). Pengaruh Edukasi Pedoman Gizi Seimbang Terhadap Pengetahuan dan Sikap Remaja Putri Kurus. Journal Of Midwifery Science, $2(2), 91$.

Sulistyoningsih, H. 2012. Gizi Untuk Kesehatan Ibu dan Anak. Jakarta : Graha Ilmu.

Sumadiyono. 2013. Sikap dan Perilaku Manusia untuk Keperawatan. Jakarta. EGC.

Wawan A, Dewi M. 2010. Teori dan Pengukuran Pengetahuan, Sikap, dan Perilaku Manusia.. Yogyakarta. Nuha Medika. 